Research Article

\title{
Prevalence of hyperprolactinemia in infertile women and its association with hypothyroidism
}

\author{
Saranya Nallusamy*, Leila J. Gracelyn
}

Department of Obstetrics \& Gynaecology, A.C.S Medical College and Hospital, Chennai, India

Received: 30 November 2015

Accepted: 12 December 2015

\section{*Correspondence:}

Dr. Saranya Nallusamy,

E-mail: drsaranyaramesh@gmail.com

Copyright: (c) the author(s), publisher and licensee Medip Academy. This is an open-access article distributed under the terms of the Creative Commons Attribution Non-Commercial License, which permits unrestricted non-commercial use, distribution, and reproduction in any medium, provided the original work is properly cited.

\section{ABSTRACT}

Background: Hyperprolactinemia is one of the common endocrinological disorders affecting fertility by causing anovulatory cycles, luteal phase defect and sex hormone imbalances. There is higher incidence of hyperprolactinemia among infertile females. So estimation of serum prolactin should be done at an early stage of infertility workup which is cost effective and causes better outcome. The objective of this study was to find out the prevalence of hyperprolactinemia in female infertility after excluding tubal factor and male factor and to find its correlation with hypothyroidism.

Methods: Hospital based analytical cross sectional study was conducted for $1 \frac{1}{2}$ years, among 300 infertile females. Females with primary and secondary infertility. Male factor infertility, females with tubal factor, history of thyroid disease/thyroid surgery/thyroid medication.

Results: Prevalence of hyperprolactinemia that is serum prolactin $>25 \mu \mathrm{g} / \mathrm{L}$ was $24.67 \%$. The mean serum prolactin level in hyperprolactinemic females was $84.83 \mu \mathrm{g} / \mathrm{L}$. Incidence of hypothyroidism in hyperprolactinemia was $25.68 \%$.Obesity (BMI >25) was present in $26 \%$ Galactorrhea was present in $20.27 \%$ females. Obesity and galactorrhea had strong positive correlation with hyperprolactinemia. Among the 300 females, 239 (79.6\%) had primary infertility and $61(20.4 \%)$ had secondary infertility.

Conclusions: Hyperprolactinemia alters the hypothalamopituitary ovarian axis and causes reproductive dysfunction. In our study, the prevalence of hyperprolactinemia was found to be high among infertile females. The relatively high occurrence of hypothyroidism among infertile females emphasizes the importance of estimating both serum prolactin and TSH in infertility.

Keywords: Hyperprolactinemia, Infertility, Hypothyroidism, Galactorrhea

\section{INTRODUCTION}

Female infertility accounts for $37 \%$ of all infertile couples \& among them most are due to ovulatory disorder, and is often associated with dysregulation of hormonal network. ${ }^{1}$ Presence of abnormally high values of prolactin, $>25 \mu \mathrm{g} / \mathrm{L}$ is termed as hyperprolactinemia which is one of the most common endocrinological disorder of the hypothalamopituitary axis affecting fertility. $^{2-4}$ Hyperprolactinemia affects the fertility potential by impairing pulsatile secretion of $\mathrm{GnRH}$ and interferes with the action of gonadotropins at the ovarian level so interfering with ovulation. ${ }^{5,6}$ Hyperprolactinemia causes galactorrhea along with menstrual and ovulatory disturbances. It is present in two thirds of women with both galactorrhea and amenorrhea. So estimation of serum prolactin levels should be done in unexplained infertility, any menstrual irregularity with or without hirsutism, galactorrhea with or without amenorrhea, luteal phase defects and anovulation. ${ }^{7}$ Mild hyperprolactinemia can cause infertility even with regular menstruation. ${ }^{8} \quad$ Women with galactorrhea and hyperprolactinemia might have primary hypothyroidism. Hypothyroidism stimulates increased secretion of TRH which stimulates thyrotrophs and lactotrophs, causing increase in the levels of both TSH \& prolactin. ${ }^{9}$ This 
study was conducted to find out the incidence of hyperprolactinemia in female infertility after excluding tubal factor and male factor and to find its association with hypothyroidism.

\section{METHODS}

\section{Study design}

Hospital based analytical cross sectional study

\section{Study period}

One and half years from April 2014 to September 2015.

\section{Study population}

300 women who attended the outpatient department, OBGY, ACS Medical College, Chennai, India.

\section{Inclusion criteria}

Women with primary and secondary infertility.

\section{Exclusion criteria}

1. Male factor infertility, female factors-tubal factor, urogenital tract anomalies and obvious organic lesion in pelvis.

2. History of thyroid disease/thyroid surgery/thyroid medication.

3. Women unwilling to participate or sign the informed consent.

\section{Ethical considerations}

Informed consent was obtained from all the participants at the start of the study. Ethical clearance was taken from the institutional ethical committee before starting the study.

\section{Proforma}

1. Detailed clinical history: Age, menarche, menstrual cycles, acne, hirsutism, marital history, drug history, galactorrhea and any visual disturbances.

2. Clinical examination: Anthropometric measurements of weight, height, BMI, breast, abdomen and pelvic examination

3. Investigations: USG abdomen and pelvis, hysterosalpingography, husband's semen analysis, serum TSH and free $\mathrm{T}_{4}$ levels by radio immuno assay (RIA) and serum prolactin levels.

With regard to raised prolactin (PRL) levels, as per WHO guidelines, PRL level $>25 \mu \mathrm{g} / \mathrm{l}$ was considered as hyperprolactinemia. ${ }^{10}$

Based on Canadian medical association, Hyperprolactinemia was categorized into ${ }^{11}$
1. Mild 26-50 $\mu \mathrm{g} / \mathrm{L}$

2. Moderate $51-75 \mu \mathrm{g} / \mathrm{L}$

3. Marked $>100 \mu \mathrm{g} / \mathrm{L}$

$\begin{array}{llll}\text { Recommendations } & \text { for } & \text { diagnosis } & \text { of } \\ \text { hyperprolactinemia }^{12} & & & \end{array}$

1. A single measurement of serum prolactin level can confirm the diagnosis if the level is above the upper limit of normal and the sample was obtained without excessive venipuncture stress. Dynamic testing of prolactin secretion is not recommended to diagnose hyperprolactinemia.

2. Macroprolactin evaluation is recommended in patients with asymptomatic hyperprolactinemia.

\section{BMI - ICMR guidelines (2008) ${ }^{13}$}

1. Normal - $18-22.9 \mathrm{~kg} / \mathrm{m} 2$

2. Overweight $-23-25 \mathrm{~kg} / \mathrm{m}^{2}$

3. Obese - $>25 \mathrm{~kg} / \mathrm{m}^{2}$

In our study, we have analysed the prevalence of hyperprolactinemia among primary and secondary infertile women, potential socio-demographic risk factors, clinical and biochemical parameters associated with hyperprolactinemia. Categorical data were analysed with the odds ratio, chi square test and the $\mathrm{p}$ value of < 0.05 was considered statistically significant. SPSS software was used for statistical analysis.

\section{RESULTS}

Table 1: Socio demographic profile of infertile women in the study.

\begin{tabular}{|llll|}
\hline \multirow{2}{*}{ Variable } & $\begin{array}{l}\text { Classification } \\
\text { of variable }\end{array}$ & $\begin{array}{l}\text { Number of } \\
\text { females } \\
(\mathbf{3 0 0})\end{array}$ & $\%$ \\
\hline \multirow{3}{*}{ Age } & $\geq 18-25$ & 106 & 35.33 \\
\cline { 2 - 4 } & $25 \leq 30$ & 128 & 42.67 \\
\cline { 2 - 4 } & $>30-35$ & 57 & 19.00 \\
\cline { 2 - 4 } & $>35$ & 9 & 3.00 \\
\hline \multirow{3}{*}{ BMI } & $<23$ & 161 & 53.67 \\
\cline { 2 - 4 } & $23-25$ & 61 & 20.33 \\
\hline Family & $>25$ & 78 & 26.00 \\
\hline History & Yes & 10 & 3.33 \\
\cline { 2 - 4 } & No & 290 & 96.67 \\
\hline
\end{tabular}

Serum prolactin level and prevalence of hyperprolactinemia in infertile females

Among the 300 infertile females, 74 had elevated serum prolactin level. The prevalence of hyperprolactinemia (>25 $\mu \mathrm{g} / \mathrm{L}$ ) was $24.67 \%$ (74/300) (Figure 1). Elevated serum prolactin level was noted in $25.5 \%$ (61/239) of primary infertility and $21.31 \%(13 / 61)$ of secondary infertility females (Figure 3). The mean serum prolactin level in hyperprolactinemic women was $84.83 \mu \mathrm{g} / \mathrm{L}$. Of 
the 300 patients, $239(60 \%)$ had primary infertility and 61 $(40 \%)$ had secondary infertility.

Out of the 74 hyperprolactinemic females, 59 had serum prolactin levels of $26-100 \mu \mathrm{g} / \mathrm{L}$ which contributes to $36.89 \%$ (59/300), 14 females had 101-200 $\mu \mathrm{g} / \mathrm{L}(9.52 \%)$. Only one female had serum prolactin $>200 \mu \mathrm{g} / \mathrm{L}$ but her brain imaging was found to be normal.

\section{Socio-demographic factors of infertile females}

Age

Most of the females were 26-30 years $(51.35 \%)$ in both infertile groups (OR 1.4; 95\% CI 0.79-2.46) followed by 18 -25years $(29.73 \%), 31-35$ years $(16.22 \%)$ and >35years
$2.7 \%$. The mean age in primary infertile females was $26.4 \mathrm{yrs}$ and in those with secondary infertility was $31.8 \mathrm{yrs}$. The mean duration of primary and secondary infertility was 2.56 years $\& 3.42$ years respectively.

Table 2: Clinical and biochemical profile of infertile women.

\begin{tabular}{|llll|}
\hline Variables & Number & $\%$ & $95 \% \mathrm{Cl}$ \\
\hline Galactorrhea & 24 & 8 & $4.93-11.07$ \\
\hline $\begin{array}{l}\text { An ovulatory } \\
\text { menstrual } \\
\text { cycles }\end{array}$ & 74 & 24.67 & $19.79-29.55$ \\
\hline Obesity & 78 & 26 & $21.04-30.96$ \\
\hline $\begin{array}{l}\text { Hypothyroidism } \\
\text { TSH }>4.6\end{array}$ & 82 & 27.33 & $22.29-32.37$ \\
\hline
\end{tabular}

Table 3: Significance of demographic, clinical and biochemical characteristics of infertile women with Hyperprolactinemia.

\begin{tabular}{|c|c|c|c|c|c|}
\hline Variable & $\begin{array}{l}\text { Classification of } \\
\text { variable } \\
\text { (total number } \\
\text { in the group) }\end{array}$ & $\begin{array}{l}\text { Number with } \\
\text { hyperprolactinemia } \\
\text { (out of 74) }\end{array}$ & $\begin{array}{l}\text { Chi- } \\
\text { square } \\
\text { value }\end{array}$ & $\begin{array}{l}\text { Odds ratio ( } 95 \% \\
\text { C.I of odds ratio) }\end{array}$ & $P$ value \\
\hline \multirow{2}{*}{ Age } & $>25$ years $(194)$ & 52 & \multirow{2}{*}{1.35} & \multirow{2}{*}{$1.4(0.79-2.46)$} & \multirow{2}{*}{0.25} \\
\hline & $\leq 25$ years $(106)$ & 22 & & & \\
\hline \multirow{2}{*}{$\begin{array}{l}\text { Family history of } \\
\text { hyperprolactinemia }\end{array}$} & Yes (10) & 4 & \multirow{2}{*}{1.3} & \multirow{2}{*}{$2.09(0.57-7.64)$} & \multirow{2}{*}{0.25} \\
\hline & No (290) & 70 & & & \\
\hline \multirow{2}{*}{ Obesity } & Yes (78) & 35 & \multirow{2}{*}{23.08} & \multirow{2}{*}{$3.82(2.17-6.72)$} & \multirow{2}{*}{$0.000003 *$} \\
\hline & No (222) & 39 & & & \\
\hline \multirow[t]{2}{*}{ Anovulation } & Yes (74) & 22 & \multirow[t]{2}{*}{1.35} & \multirow[t]{2}{*}{$1.42(0.79-2.55)$} & \multirow[t]{2}{*}{0.25} \\
\hline & No (226) & 52 & & & \\
\hline \multirow{2}{*}{ Galactorrhea } & Yes (24) & 15 & \multirow{2}{*}{20.03} & \multirow{2}{*}{$6.13(2.56-14.71)$} & \multirow{2}{*}{$0.000009 *$} \\
\hline & No (276) & 59 & & & \\
\hline \multirow{2}{*}{ Hypothyroidism } & No (218) & 55 & \multirow{2}{*}{0.14} & \multirow{2}{*}{$1.12(0.62-2.03)$} & \multirow{2}{*}{0.71} \\
\hline & Yes (82) & 19 & & & \\
\hline
\end{tabular}

\section{Family history of hyperprolactinemia}

Only $3.33 \%$ (16 patients) of infertile women (Table 1) showed positive family history of hyperprolactinemia. Among the elevated serum prolactin group, only 4 females $(5.41 \%)$ were having family history of hyperprolactinemia. In similar to other studies, which shows that no association exists between elevated serum prolactin level and family history of hyperprolactinemia, our statistics also showed a negative correlation (OR 2.09 ; $95 \%$ C.I $-0.57-7.64)$.
The incidence of hypothyroidism in infertility was $27.33 \%$ (82/300) with 95\% CI: 22.29-32.37 (Table-2). Presence of hypothyroidism in hyperprolactinemia was $25.5 \%$ i.e. 19 out of 74 (OR 1.12; 95\% CI: 10.62-2.03) Table -3 . The mean serum prolactin level in hypothyroid women was $27.36 \mu \mathrm{g} / \mathrm{L}$. The ratio of proportions between hyperprolactinemia and hypothyroidism was 4:1 i.e. in every four hyperprolactinemic females one had hypothyroidism. The statistical correlation between hypothyroidism and elevated prolactin level was insignificant ( $\mathrm{p}$ value 0.71 ) as seen in Table 3.

\section{Hypothyroidism and elevated serum prolactin levels}




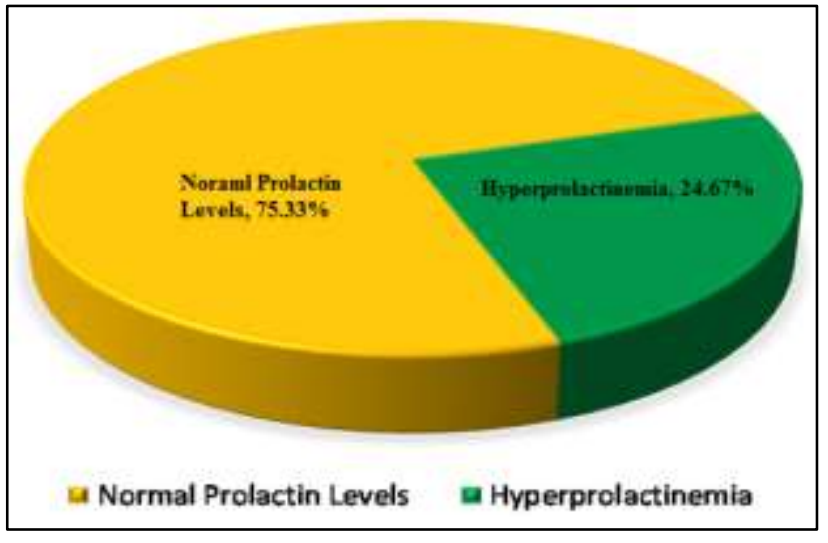

Figure 1: Prevalence of hyperprolactinemia in infertile women.

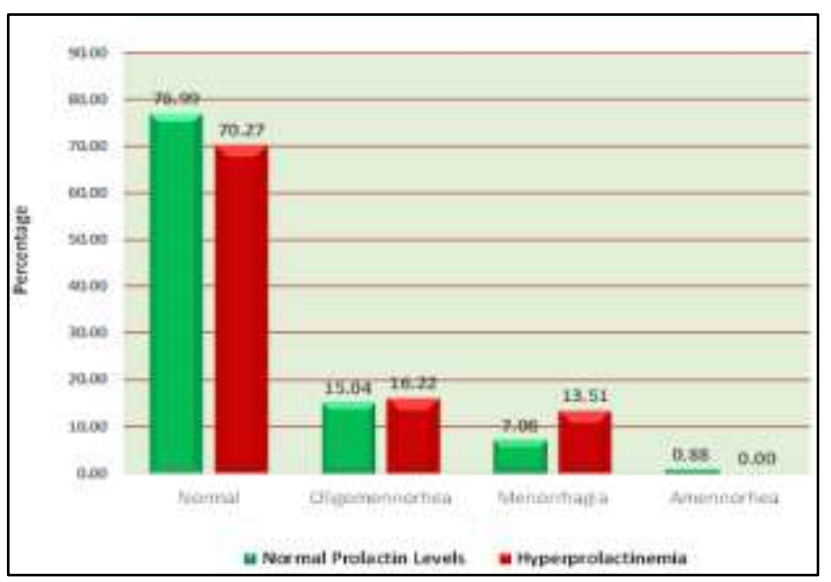

Figure 2: Menstrual disturbances in infertile women.

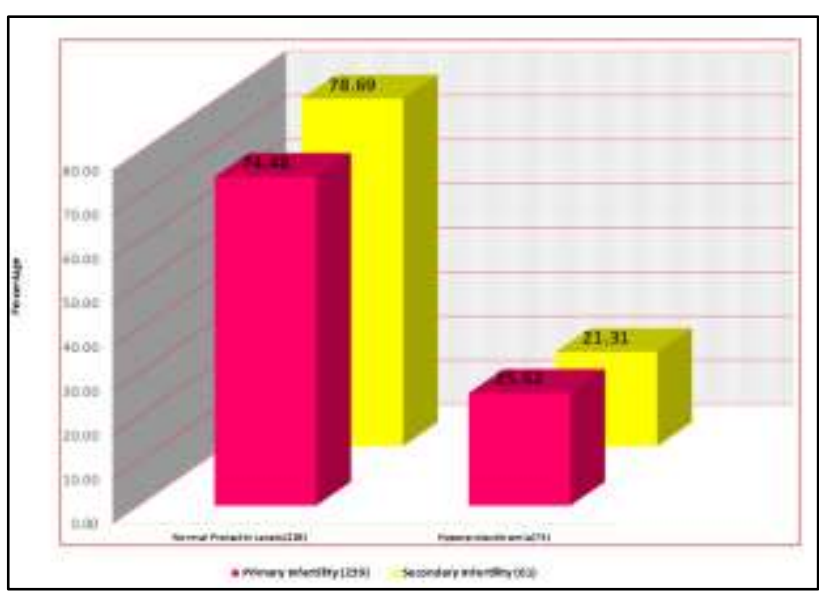

Figure 3: Prolactin levels in patents with primary and secondary infertility.

\section{Galactorrhea and hyperprolactinemia}

Galactorrhea was present in $8 \%$ (24 females) of infertile females with 95\% CI 4.93-11.07 (Table -2), among them 15 were hyperprolactinemic. Galactorrhea was either the chief complaint or was detected on clinical examination. The mean serum prolactin level in women with galactorrhea was $54.58 \mu \mathrm{g} / \mathrm{L}$. Out of the 74 women with hyperprolactinemia, 15(20.27\%) had galactorrhea. We found strong correlation between galactorrhea and elevated serum prolactin (OR 6.13 with $95 \%$ CI 2.5614.71) with significant $p$ value 0.000009 (Table 3 ).

\section{BMI and obesity}

BMI >25 was present in 78 infertile females, that is $26 \%$ of total (95\% CI 21.04-30.96). Out of the 78females, $35(47.3 \%)$ were hyperprolactinemic (OR 3.82; 95\% CI 2.17-6.72). Association between obesity and hyperprolactinemia was significant with $p$ value of 0.000003 (Table 3).

\section{Menstrual dysfunction}

Normal menstrual cycles were present in $75.4 \%$ (226/300) infertile patients, remaining 24.6\% (74/300) showed some menstrual abnormality with $95 \%$ CI 19.79 29.55. Among the 74 patients with abnormal menstruation, $22 \quad(29.7 \%)$ patients were hyperprolactinemic. In females with elevated prolactin, $70 \%$ had normal menstrual cycles, oligomenorrhea was present in $16.2 \%$ and menorrhagia in $13.5 \%$ and none had amenorrhea (Figure 2). Anovulation present in $29.73 \%$ (OR 1.42, 95\% CI 0.79-2.55) of hyperprolactinemic females. This finding was contrary to other studies.

In hysterosalpingography, all the patients had patent fallopian tubes as none with tubal factor infertility was included in this study. Ultrasonogram didn't show any obvious organic pelvic pathology which causes infertility.

Fifteen women (19.67\%) had prolactin levels $>100 \mathrm{ng} / \mathrm{mL}, 12$ with primary infertility and 3 with secondary infertility. All the 15 were advised CT scan or MRI and pituitary adenoma was found in one female with serum prolactin level $165 \mathrm{ng} / \mathrm{mL}$. The remaining 14 showed normal findings.

The most common cause of hyperprolactinemia in our study was idiopathic, followed by primary hypothyroidism.

\section{DISCUSSION}

Hyperprolactinemia is one of the most common endocrinological disorders affecting fertility. ${ }^{14}$ The understanding that hyperprolactinemia not only manifests as galactorrhea and amenorrhea but also causes gonadal dysfunction and infertility led to the estimation of prolactin in infertile females.

The prevalence of hyperprolactinemia according to various studies, in Avasti et al study 46\% (111 patients), In Goswami et al study $41 \%$ (160 patients), In Akhter \& Hassan et al study $37.5 \%$, Salah et al study $33.3 \%(150$ patients), In Indu Verma et al study $13.7 \%$ (54 out of total 394 patients), in our study prevalence of 
hyperprolactinemia was $24.67 \% .^{8,15-17}$ Stress is one of the factor affecting prolactin secretion, variable prevalence may be due to different stress levels in various regions.

In Akhter \& Hassan et al study $43 \%$ females had primary infertility and $22 \%$ had secondary infertility. ${ }^{16}$ In Muhammad et al study primary infertility was $55.7 \%$ and secondary infertility was $44.3 \% .^{18}$ In Avasti et al study on 111 infertile pts showed 60\% (67 females) primary and $40 \%$ (44 females) secondary infertility. ${ }^{7}$ Similar results were found in Sharma et al study. ${ }^{19}$ In our study, there were $79.6 \%$ (239) women with primary infertility and $20.4 \%$ (61) women with secondary infertility. Secondary infertility females may seek consultation less frequently because they already had pregnancy. Among the 239 primary infertility and 61 secondary infertility females, $25.5 \% \quad(61 / 239)$ and $21.3 \% \quad(13 / 61)$ were hyperprolactinemic respectively.

Hyperprolactinemia decreases the GnRH pulsatile release and impairs FSH, LH secretion. It also affects the steroidogenic activity of ovarian follicles and causes inadequate progesterone secretion in luteal phase ${ }^{(18) .}$ All these results in luteal phase defect, inconstant ovulation and chronic anovulation. Luteal insufficiency impairs endometrial growth and affects the implantation of embryo. $^{20}$ This accounts for $3-10 \%$ of infertility and two thirds of these females had hyperprolactinemia. ${ }^{21}$ In hyperprolactinemic infertility, the best treatment to increase conception rate is to lower prolactin secretion with dopaminergic drugs. ${ }^{22}$

Association between hypothyroidism and hyperprolactinemia in our study was $25.5 \%$ which is similar to Avasti et al study. ${ }^{7}$ In Chowdhury and Goswami et al study $16.6 \%$, Singh et al study $57 \%$, Indu Verma et al study $4.57 \%$ (total 394 patients), Binita Goswami et al study $46.1 \%$ (total 160 patients). ${ }^{14,15,17,23}$ From the above data, estimation of both TSH and prolactin levels are important in infertility evaluation. The raised TRH secretion in primary hypothyroidism stimulates both TSH and prolactin secretion. In infertile females if hypothyroidism is associated with hyperprolactinemia, hypothyroidism should be treated first and TSH should be maintained at lower limit.

Significant association was noted between obesity and hyperprolactinemia. So all obese infertile females should have serum prolactin estimation. Serum prolactin and TSH levels showed significant positive correlation with body weight and BMI in secondary infertility. Obesity is associated with hormonal derangements which are responsible for infertility. ${ }^{25}$ This is contrast to a recent study in general population where there was no correlation found between serum prolactin and obesity. ${ }^{26}$ Conversely, another study comparing basal and TRH stimulated prolactin levels in obese and non-obese individuals showed higher basal levels of prolactin in obese individuals. ${ }^{27}$ In overweight women with infertility, weight loss should be considered as a first line treatment.
To reduce $\mathrm{BMI}$, to prevent obesity related metabolic changes and to improve fertility, life style modification should be advised.

In our study $24.6 \%$ of females were having abnormal menstrual cycles, this is contrast to other studies. In Avasti et al study $57.6 \%$, in Muhammad et al study $90.2 \%$, in Akhther et al study it was $70 \%$, Salah et al study $66.7 \%$ (150 patients), in Goswami B et al study $61.2 \% .^{8,15,16,18}$ Mild to moderate hyperprolactinemia does not correlate with either the degree or presence/absence of menstrual disturbances. ${ }^{24}$ Prevalence of ovulatory dysfunction, as one of the causes of female infertility, has been variously reported in different studies.

\section{CONCLUSION}

$24.67 \%$ of infertile women had raised prolactin levels and $25.6 \%$ of women were having hypothyroidism associated with hyperprolactinemia. In hypothyroid infertile women if associated with hyperprolactinemia, the first treatment should be to correct the hypothyroidism and maintain TSH at lower limit. Association between galactorrhea \& obesity with hyperprolactinemia is significant, so serum prolactin estimation should be done in infertile females either with galactorrhea or obesity. Lifestyle modification should be advised to reduce BMI along with or prior to infertility treatment. Mild hyperprolactinemia can cause infertility even with regular menstruation. Hyperprolactinemia is one of the most common endocrinological disorders of female infertility and it is often associated with hypothyroidism. So all infertile women should be offered serum prolactin and Thyroid Stimulating Hormone (TSH) estimation at an early stage of infertility checkup rather than going for more costly tests or invasive procedures.

\section{Funding: No funding sources}

Conflict of interest: None declared

Ethical approval: The study was approved by the institutional ethics committee

\section{REFERENCES}

1. Unuane D, Tournaye H, Velkeniers B, Poppe K. Endocrine disorders \& female infertility. Best Prac Res Clin Endocrinol Metab. 2011;25(6):861-73.

2. Rosato F, Garofalo P. Hyperprolactinemia: from diagnosis to treatment. Minerva pediatrica. 2002;54(6):547-52.

3. Ratner LD, Gonzalez B, Ahtiainen P, Di Giorgio NP, Poutanen M. Short-term pharmacological suppression of the hyperprolactinemia of infertile hCG-overproducing female mice persistently restores their fertility. Endocrinology. 2012;153(12):5980-92.

4. Berinder K, Hulting AL, Granath F, Hirschberg AL, Akre O. Parity, pregnancy and neonatal outcomes in women treated for hyperprolactinaemia compared 
with a control group. Clin Endocrinol. 2007;67(3):393-7.

5. Poppe K, Velkeniers B. Thyorid disorders in infertile women. Ann Endocriniol (Paris). 2003;64(1):45-50.

6. Zollner U, Lanig K, Steck T, Dietl J. Assessment of endocrine status in patients undergoing in-vitro fertilization treatment. Is it necessary? Arch Gynecolo obstet. 2001;265(1):16-20.

7. Avasti kumkum,kaur jasmine,Gupta Shweta. Hyperprolactinemia and its correlation with hypothyroidism in infertile women $\mathrm{J}$ obstet gynecol India. 2006;56:68-71.

8. Eldin S, Abdelghani A, Elmagadum A. Hyperprolactinemia as a cause of female infertility and its prevalence in central Sudan. Egypt Acad. J.Biolog. Sci. 2013;5(1):31-6.

9. Shoupe D, Mishell DR. Hypoprolactinemia: Diagnosis and treatment. In: Mishell's textbook of Infertility, Contraception and Reproductive Endocrinology.. Massachusetts. Blackwell Science. 1997;4:323-41.

10. Melmed S, Casanueva FF, Hoffman AR, Kleinberg DL, Montori VM, Schlechte JA. Diagnosis and treatment of hyperprolactinemia: an Endocrine Society clinical practice guideline.J Clin Endocrinol Metab. 2011;96:273-88.

11. Serri O, Chik CL, Ehud Ur, Ezzat S. Diagnosis and management of hyperprolactinemia. Canadian Medical Association Journal. 2003;169(6):575-81.

12. Barclay L, Lie D. Endocrine Society Issues Guidelines for Management of Hyperprolactinemia. J Clin Endocrinol Metab. 2011;96:273-88.

13. Misra A, Chowbey P, Makkar BM, Vikram NK, Wasir JS, Chadha D. Consensus statement for diagnosis of obesity, abdominal obesity and the metabolic syndrome for Asian Indians and recommendations for physical activity, medical and surgical management. J Assoc. Physicians India. 2009;57:163-70.

14. Choudhary SD, Goswami A. Hyperprolactinemia and reproductive disorder a profile from north east. J Assoc Physicians India. 1995;43:617-8.

15. Goswami B, Patel S, Saxena A. correlation of prolactin and thyroid hormone concentration with menstrual pattern in infertile women. J Reprod Infertility. 2009;10(3):207-12.

16. Akhter N, Hassan S. Sub-clinical hypothyroidism and hyperprolactinemia in infertile women: Bangaladesh perspective after universal salt iodination. the internet journal of endocrinology. 2008;5(1).

17. Verma I, Sood R, Juneja S, Kaur S. Prevalence of hypothyroidism in infertile women and evaluation of response of treatment for hypothyroidism on infertility. Int J Appl Basic Med Res. 2012;2(1):179.

18. Muhammad O, Bushra J. Physiological study of some Hormonal Parameters in Infertile Hyperprolactinemic Women in Pre and Post Treatment with Cabergoline and Bromocriptine. Medical journal of Babylon. 2012;9(2):349-61.

19. Sharma N, Baliarsingh S, Kaushik GG. Biochemical association of hyperprolactinemia with hypothyroidism in infertile women. Clin Lab. 2012;58(7-8):805-10.

20. Dizerega GS, Ross GT. Luteal phase dysfunction. Clin Obstet Gynecol. 1981;8:733-51.

21. Shibli-Rahhal A, Schlechte J. Hyperprolactinemia and infertility. Endocrinol Metab Clin N Am. 2011;40:837-46.

22. Crosignani PG. Management of hyperprolactinemic infertility. Middle East Fertility Society Journal. 2012;17:63-69.

23. Singh L, Agarwal CG, Chowdhary SR. Thyorid profile in infertile women. J. Obstet Gynecol India. 1990;40:248-53.

24. Souter I, Baltagi LM, Toth TL, Petrozza JC. Prevalence of hyperprolactinemia and abnormal magnetic resonance imaging findings in a population with infertility. Fertil Steril 2010;94:1159-62.

25. Seth B, Arora S, Singh R. Association of Obesity with Hormonal Imbalance in Infertility-A CrossSectional Study in North Indian Women. Ind J Clin Biochem. 2013;28(4):342-7.

26. Ernst B, Thurnheer M, Schultes B. Basal serum prolactin levels in obesity-unrelated to parameters of the metabolic syndrome and unchanged after massive weight loss. Obes Surg. 2009;19(8):115962.

27. Grimaldi F, Mazzolini A, Paterniti BR, Torossi I, Proto G, Bertolissi F. Changes in secretion of prolactin in obesity. Minerva Endocrinol. 1990;15(4):267-71.

Cite this article as: Nallusamy S, Gracelyn LJ.

Prevalence of hyperprolactinemia in infertile women and its association with hypothyroidism. Int $\mathbf{J}$ Adv Med 2016;3:33-8. 